\title{
Minerals consumption by Acetobacter xylinum on cultivation medium on coconut water
}

\author{
Denise Milleo Almeida ${ }^{1,2}$, Rosilene Aparecida Prestes ${ }^{3}$, Adriel Ferreira da Fonseca ${ }^{4}$, \\ Adenise L.Woiciechowski ${ }^{1}$, Gilvan Wosiacki ${ }^{1,3}$ \\ ${ }^{1}$ Programa de Pós-Graduação em Processos Biotecnológicos, \\ Universidade Federal do Paraná, Curitiba, PR, Brazil. \\ ${ }^{2}$ Departamentos de Alimentos, Universidade Tecnológica Federal do Paraná, \\ Campus Ponta Grossa, Ponta Grossa, PR, Brazil. \\ ${ }^{3}$ Programa de Pós-Graduação em Ciências e Tecnologia de Alimentos, \\ Universidade Estadual de Ponta Grossa, Ponta Grossa, PR, Brazil. \\ ${ }^{4}$ Departamento de Ciência do Solo e Engenharia Agrícola, \\ Universidade Estadual de Ponta Grossa, Ponta Grossa, PR, Brazil.
}

Submitted: January 20, 2011; Approved: July 2, 2012.

\begin{abstract}
The objective of this work is to verifying the consume of the minerals $\mathrm{K}, \mathrm{Na}, \mathrm{Fe}, \mathrm{Mg}, \mathrm{P}, \mathrm{S}-\mathrm{SO}_{4}{ }^{-2}, \mathrm{~B}, \mathrm{~N}$ Total Kjedahl (NTK), $\mathrm{NO}_{3}{ }^{-}-\mathrm{N}$, and $\mathrm{NH}_{4}{ }^{+}-\mathrm{N}$ in the production of bacterial cellulose by Acetobacter xylinum, according to the medium and the manner of cultivation. The fermentative process was in ripe and green coconut water. $\mathrm{K}$ and $\mathrm{Na}$ were determined by flame emission photometry, $\mathrm{Mg}$ and $\mathrm{Fe}$ by atomic absorption spectrophotometry, $\mathrm{P}$ by molecular absorption spectrophotometry, $\mathrm{S}^{-\mathrm{SO}_{4}}{ }^{-2}$ by barium sulphate turbidimetry, B by Azomethin- $\mathrm{H}$ method, NTK by Kjeldahl method, $\mathrm{N}^{-\mathrm{NO}_{3}{ }^{-} \text {and }}$ $\mathrm{N}-\mathrm{NH}_{4}{ }^{+}$by vapor distillation with magnesium oxide and Devarda's alloy, respectively. In Fermentation of ripe coconut water there were higher consumption of $\mathrm{K}(69 \%), \mathrm{Fe}(84,3 \%), \mathrm{P}(97,4 \%)$, $\mathrm{S}_{-} \mathrm{SO}_{2}^{-2}(64,9 \%), \mathrm{B}(56,1 \%), \mathrm{N}^{-} \mathrm{NO}_{3}{ }^{-}(94,7 \%)$ and $\mathrm{N}-\mathrm{NH}_{4}{ }^{+}(95,2 \%)$, whereas coconut water of green fruit the most consumed ions were $\mathrm{Na}(94,5 \%), \mathrm{Mg}(67,7 \%)$ and NTK $(56,6 \%)$. The cultivation under agitation showed higher mineral consumption. The higher bacterial cellulose production, $6 \mathrm{~g} . \mathrm{L}^{-1}$, was verified in the coconut water fermentative in ripe fruit, added $\mathrm{KH}_{2} \mathrm{PO}_{4}, \mathrm{FeSO}_{4}$ and $\mathrm{NaH}_{2} \mathrm{PO}_{4}$ kept under agitation.
\end{abstract}

Key words: minerals, bacterial cellulose, Acetobacter xylinum.

\section{Introduction}

Bacterial cellulose $(\mathrm{BC})$ is a exopolysaccharide produced by some strains of Acetobacter, which have peculiar physical and chemical properties, such as ultrathin cellulose ribbons, high degree of polymerization and crystallinity, absence of lignin and hemicellulose, high tension force and elasticity, elevated capacity of retaining water, high porosity, chemical purity and biodegradability (Chávez-Pacheco et al., 2004; Jonas and Farah, 1988; Okiyama et al., 1992; Saxena et al., 1994; Vandamme et al., 1998). However, attributes as yield and BC structure are directly related to the method and culture medium (Krystynowicz et al., 2002; Park et al., 2009; Son et al., 2001). Thus, the functional properties of the biopolymers are important tools for the development of new textures for various uses in general industry.

Many studies show that, for a good production of bacterial cellulose by strains of Acetobacter, culture media enriched with carbohydrates, proteins, vitamins, and inorganic salts are required (Baruque-Ramos et al., 2001; Budhiono et al., 1999; Chávez-Pacheco et al., 2005; Jagannath et al., 2009; Jonas and Farah, 1988; Son et al., 2003). In spite of being present in low concentrations, those miner- 
als have a significant effect in the growing and production of bacterial cellulose (Weinhouse and Benziman, 1974).

Elements like sodium $(\mathrm{Na})$, potassium $(\mathrm{K})$, calcium $(\mathrm{Ca})$, magnesium $(\mathrm{Mg})$ and iron $(\mathrm{Fe})$ are nutrients that play an important part in the production of bacterial polysaccharides, because they are enzymatic cofactors in the production of such polysaccharides (Martins et al., 1990; Wong, 1993). As a source of phosphorus (P), it is common to used soluble phosphates, with $\mathrm{Ca}, \mathrm{K}, \mathrm{Na}, \mathrm{Fe}$, copper $(\mathrm{Cu}), \mathrm{Mg}$, manganese $(\mathrm{Mn})$, cobalt $(\mathrm{Co})$, among other minerals, in low concentrations (Lima et al., 2001). Ferric ions $\left(\mathrm{Fe}^{3+}\right)$ are oxygenase cofactors, and also comes from the protein respiratory chain, the cytochromes, which mediate the production of high energy phosphoric composites such as ATP (adenosine triphosphate), and UTP (uridine triphosphate), participating of the bacterial polyssacharides biosynthesis (Nohata and Kurane, 1997).

Sulfur (S) is part of the amino acids cysteine and methionine, vitamins, and prosthetic groups from various important proteins in reduction-oxidation reactions. The sulfates $\left(\mathrm{SO}_{4}{ }^{-2}\right)$ and the amino acids are preferably consumed by the bacteria (Trabulsi, 1999).

In the production of bacterial cellulose by Acetobacter sp. A9, magnesium is important for the maintenance of cellular metabolism; the element is also essential for the growing and production of cellulose (Son et al., 2001), because it participates directly in the enzyme cellulose syntheses activities, activated by oligonucleotide guanil (Fontana et al., 1997, Ross et al., 1986) and it is important in the linking process among the microfibrils subunits (Saxena and Brown, 2001).

The effects of various nutrients in the production of bacterial cellulose by strains of Acetobacter sp. V6 were verified, and it was noticed that the inorganic salts $\mathrm{MgSO}_{4}$ $7 \mathrm{H}_{2} \mathrm{O}, \mathrm{FeSO}_{4} 7 \mathrm{H}_{2} \mathrm{O}$, and $\mathrm{H}_{3} \mathrm{BO}_{3}$ represented an increase in production when added in the concentrations of $0.08 \%$, $0.0005 \%$, and $0.0003 \%$, respectively (Son et al., 2003).

The objective of this work was verifying the consume of the minerals K, Na, Fe, Mg, P, S-SO ${ }_{4}^{-2}$, Boron (B), N Total Kjedahl (NTK), $\mathrm{NO}_{3}{ }^{-} \mathrm{N}$, and $\mathrm{NH}_{4}{ }^{+}-\mathrm{N}$ in the production of bacterial cellulose by Acetobacter xylinum, according to the medium and the manner of cultivation.

\section{Materials and Methods}

\section{Production of bacterial cellulose}

In the fermentation process, it was used Acetobacter xylinum (ATCC 23769) come from the André Tosello Foundation, Campinas-SP, Brazil, cultivated in ripe and green coconut water. The experimental design used was duplicated fractional factorial $2^{7-2}$ with 32 treatments. The independent variables were: means of cultivation (with or without agitation at $100 \mathrm{rpm}$ in a bacteriological incubator (Marconi - MA 832, São Paulo, Brazil) and with or without the adding of salts $\left(\mathrm{NH}_{4}\right)_{2} \mathrm{SO}_{4}\left(600 \mathrm{mg} \cdot \mathrm{L}^{-1}\right), \mathrm{KH}_{2} \mathrm{PO}_{4}$
(5000 mg. $\left.\mathrm{L}^{-1}\right), \quad \mathrm{MgSO}_{4} \cdot 7 \mathrm{H}_{2} \mathrm{O}\left(200 \mathrm{mg} \cdot \mathrm{L}^{-1}\right), \quad \mathrm{NaH}_{2} \mathrm{PO}_{4}$ (300 mg. $\left.\cdot \mathrm{L}^{-1}\right), \mathrm{FeSO}_{4}\left(5 \mathrm{mg} \cdot \mathrm{L}^{-1}\right)$ and $\mathrm{H}_{3} \mathrm{BO}_{3}\left(3 \mathrm{mg} \cdot \mathrm{L}^{-1}\right)$ (Vetec). The dependent variable observed was the yield of the bacterial cellulose produced $\left(\mathrm{g} . \mathrm{L}^{-1}\right)$ in dry weight.

\section{Samples preparation}

The coconut water from ripe and green fruit was put in a tank with constant manual agitation, for homogenization. Then, the medium was transferred to $500 \mathrm{~mL}$ Erlenmeyers, which contained the minerals according to the experimental design, in portions of $300 \mathrm{~mL}$. The $\mathrm{pH}$ (Tecnal - Pec-2MP, São Paulo, Brazil) of the medium was adjusted to $5.0( \pm 0.01)$ with acetic acid $1 \mathrm{~mol} . \mathrm{L}^{-1}$ and sodium hydroxide (Vetec) 1 mol.L $\mathrm{L}^{-1}$, followed by autoclave sterilization at $121^{\circ} \mathrm{C}$ during $20 \mathrm{~min}$. After that, the microorganism, conserved in a maintenance medium ALABAN (100 g. $\mathrm{L}^{-1}$ sucrose; 5 g.L $\mathrm{L}^{-1} \mathrm{KH}_{2} \mathrm{PO}_{4} ; 2.5$ g. $\mathrm{L}^{-1}$ yeast extract; 0.2 g. $\mathrm{L}^{-1} \mathrm{MgSO}_{4} .7 \mathrm{H}_{2} \mathrm{O} ; 0.6$ g.L $\left.\mathrm{L}^{-1}\left(\mathrm{NH}_{4}\right)_{2} \mathrm{SO}_{4}\right)$, was inoculated at $5 \%(\mathrm{v} / \mathrm{v})$. In the work, the Fermentations of Ripe Coconut Water are nominated as FRCW and the Fermentations of Green Coconut Water as FGCW.

\section{Quantification of ion concentration and yield of bacterial cellulose}

The concentrations of the minerals $\mathrm{K}, \mathrm{Na}, \mathrm{Fe}, \mathrm{Mg}, \mathrm{P}$, $\mathrm{S}-\mathrm{SO}_{4}^{-2}, \mathrm{~B}, \mathrm{NTK}, \mathrm{NO}_{3}^{-}-\mathrm{N}, \mathrm{NH}_{4}{ }^{+}-\mathrm{N}$ were determined in the treatments with production of bacterial cellulose higher than 4 g. $\mathrm{L}^{-1}$. The analysis occurred in the beginning (zero hour) and at the end ( $168 \mathrm{~h})$ of the fermentation process. All the analysis was made according to Malavolta et al. (1997).

Each sample was divided into two sets: unfiltered and filtered through a $0.45 \mathrm{~mm}$ pore ester-cellulose membrane. Unfiltered samples were submitted to analysis for the organic and ammonium $\mathrm{N}$ by using sulfuric acid digestion and the semi micro-Kjeldahl method. The solid particle fraction, retained in the ester-cellulose membrane after the filtering of the second set was submitted to dry digestion in a furnace at $550^{\circ} \mathrm{C}$ during $6 \mathrm{~h}$, and from this moment on they were labeled digested. After that, the ashes were solubilized in a hydrochloric acid $0.1 \mathrm{~mol} . \mathrm{L}^{-1}$ solution and then refrigerated until analysis. The sub samples filtrated were divided in two parts, half was preserved in concentrated nitric acid (three drops for each $20 \mathrm{~mL}$ extract) and then refrigerated until analysis of the minerals $\mathrm{K}, \mathrm{Na}, \mathrm{Fe}$ and MG, and the other half was kept frozen until the analysis of $\mathrm{P}$, $\mathrm{S}-\mathrm{SO}_{4}{ }^{-2}, \mathrm{~B}, \mathrm{~N}-\mathrm{NO}_{3}{ }^{-}$and $\mathrm{N}-\mathrm{NH}_{4}{ }^{+}$. The filtrated and digested samples were used to determine the following parameters: $\mathrm{K}$ and $\mathrm{Na}$ by flame emission photometry (FEP) (Micronal, B-262, São Paulo, Brazil); Fe and Mg determined by atomic absorption spectrophotometry (AAS) (Varian AAS 240 FS, São Paulo, Brazil); P by molecular absorption spectrophotometry (MAS) (Tecnal - Bel SP 1150, São Paulo, Brazil); $\mathrm{S}_{-} \mathrm{SO}_{4}{ }^{-2}$ by barium sulphate turbidimetry (Tecnal - Bel SP 1150, São Paulo, Brazil); B by the Azomethin-H method; N Total Kjedahl (NTK) concentrations 
were determined by Kjedahl method, and $\mathrm{NH}_{4}{ }^{+} \mathrm{N}$ and $\mathrm{NO}_{3}{ }^{-}-\mathrm{N}$ concentrations were determined by vapor distillation (Distiller Nitrogen - MA 036 Plus, São Paulo, Brazil) with magnesium oxide $(\mathrm{MgO})$, and with Devarda's alloy, respectively.

The remainder of the culture media was let to fermentation in a sterilizer at $30^{\circ} \mathrm{C}$ for $168 \mathrm{~h}$. After this period, the fermented material was submitted to the same procedures of preparation and analysis.

\section{Multivariate and statistic analysis}

Mineral concentration data were submitted to variance and regression analysis. Regression equations were adjusted to the obtained data according to time and treatment; the magnitude of determination coefficients ( $p \leq 0.05)$ was used as the criteria of choice.

The exploratory analysis of the percentage values of mineral concentration was performed by principal components analysis (PCA). The principal components analysis was constructed from a $52 \times 10$ data matrix, that is, 52 treatments considering initial time (zero hour) and final (168 h) of the fermentative process, and 10 variables related the minerals. The samples were divided in four classes: Fermented Ripe Coconut Water zero hour (FRCW-0 h) and 168 h (FRCW-168 h); Fermented Green Coconut Water zero hour (FGCW-0 h) and $168 \mathrm{~h}$ (FGCW-168 h). Those models were performed using the software Pirouette 4.0 (Infometrix).

\section{Results and Discussion}

\section{Minerals consumption of in coconut water fermented}

In this research, the treatments with bacterial cellulose (BC) yield variation of 4 to 4.1 g. $\mathrm{L}^{-1}, 4.2$ to 4.9 g. $\mathrm{L}^{-1}$ and 5 to 6 g.L $\mathrm{L}^{-1}$ were considered low, moderated, and high, respectively. The classification was made according to data collection of production and productivity reported in the literature (Budhiono et al., 1999; García et al., 1974; Krystynowicz et al., 2002; Kurosumi et al., 2009; Kyazanova et al., 2009; Masaoka et al., 1993; Okiyama et al., 1992; Park et al., 2009; Son et al., 2003). Thus, the treatments 8 and 11; 15,22 and $27 ; 18,19,20$, and 23 of fermented ripe coconut water had low production of bacterial cellulose (L-BC), moderated production of cellulose (M-BC), and high production of bacterial cellulose (H-BC), respectively. The treatments 3, 9, 11 and 18; 7, 10, 12, 13, 20, 23, 24 and 26; 16 and 27 of fermented green coconut water had low production of bacterial cellulose (L-BC), moderated production of bacterial cellulose (M-BC), and high production of bacterial cellulose (H-BC), respectively (Table 1).

Mineral concentrations in the beginning and at the end of the fermentative process are in Tables 2 and 3.

Considering the manner of cultivation, the treatments maintained under agitation had a high consumption of minerals, in both fermentations (Table 4).
In fermented ripe coconut water, under agitation, high consumptions were verified in treatments $11(\mathrm{~L}-\mathrm{BC})$, 15 (M-BC), 18 and 23 (H-BC), being those minerals $\mathrm{NO}_{3}{ }^{-} \mathrm{N}$; $\mathrm{Na}$ and $\mathrm{NTK} ; \mathrm{K}, \mathrm{Fe}$ and $\mathrm{NH}_{4}{ }^{+}-\mathrm{N}$, respectively. In fermented green coconut water, under agitation, treatments 10 (M-BC), 11 (L-BC) and 23 (M-BC) had high mineral consumption, being those minerals B, S, and NTK; $\mathrm{Mg}$ and $\mathrm{NTK} ; \mathrm{K}$ and $\mathrm{Na}$, respectively. In fermented ripe coconut water, treatments maintained under agitation with high production of bacterial cellulose, 23 (H-BC) and 19 (H-BC), showed high consumption of $\mathrm{NH}_{4}{ }^{+}-\mathrm{N}$ and $\mathrm{NO}_{3}{ }^{-}-\mathrm{N}$, respectively. However, in fermentations of green coconut water, the high production of cellulose was verified in treatments 16 (H-BC) and 27 (H-BC), in static conditions, both with high consumption of $\mathrm{NO}_{3}^{-}-\mathrm{N}$.

Considering the production of bacterial cellulose (Table 5), in fermented ripe coconut water, between the treatments of low yield showed high average consumption of $\mathrm{NO}_{3}{ }^{-} \mathrm{N}(87.7 \%)$; the treatments of moderated yield presented high average consumption of $\mathrm{Na}(69.1 \%)$ and $\mathrm{P}$ (91.1\%); while the treatments of high yield were related to higher average consumption of $\mathrm{NO}_{3}{ }^{-}-\mathrm{N} \quad(86.3 \%)$ and $\mathrm{NH}_{4}{ }^{+}-\mathrm{N}(84.6 \%)$. Among the minerals $\mathrm{K}, \mathrm{Na}, \mathrm{Fe}, \mathrm{Mg}, \mathrm{P}$, $\mathrm{S}-\mathrm{SO}_{4}{ }^{-2}, \mathrm{~B}, \mathrm{NTK}, \mathrm{NO}_{3}^{-}-\mathrm{N}$ and $\mathrm{NH}_{4}^{+}-\mathrm{N}$, the higher consumption were observed in treatments 18 (H-BC) 69.0\%; 15 (M-BC) 69.1\%; 23 (H-BC) 84.1\%; 27 (M-BC) 32.9\%; 27 (M-BC) 97.4\%; 27 (M-BC) 64.9\%; 33 (L-BC) 56.1\%; 15 (M-BC) 55.2\%; 11 (L-BC) 94.7\%; 23 (H-BC) 95.2\%, respectively. Among the minerals $\mathrm{K}, \mathrm{Na}, \mathrm{Fe}, \mathrm{Mg}, \mathrm{P}$, $\mathrm{S}_{-} \mathrm{SO}_{4}{ }^{-2}, \mathrm{~B}, \mathrm{NTK}, \mathrm{NO}_{3}{ }^{-}-\mathrm{N}$ and $\mathrm{NH}_{4}{ }^{+}-\mathrm{N}$, the lowest consumption were observed in treatments 23 (H-BC) 42.2\%; 22 (M-BC) 39.4\%; 15 (M-BC) 14.2\%; 22 (M-BC) 0.6\%; 23 (H-BC) $53.3 \%$; 19 (H-BC) 3.5\%; 15 (M-BC) $0.6 \% ; 19$ (H-BC) $1.1 \%$; 22 (M-BC) 50.5\%; 20 (H-BC) 17.5\%, respectively.

It was observed that the $\mathrm{NO}_{3}{ }^{-}-\mathrm{N}$ did not directly influence the bacterial cellulose production because there was a large consumption of this mineral such in the treatments with higher and with low bacterial cellulose production. The suggestion is that the consumption has to be designated to the microbial development. Nitrogen is a main component of proteins necessary in cell metabolism, and comprises $8-14 \%$ of the dry cell mass of bacteria. The addition of extra nitrogen favours the biomass production, but diminishes cellulose production (Masaoka et al., 1993).

In fermented ripe coconut water, the minerals $\mathrm{K}$, $\mathrm{B}$ and $\mathrm{S}_{-} \mathrm{SO}_{4}{ }^{-2}$, with percentage of explained variance greater than $90 \%$, were submitted to regression analysis, and demonstrated significant difference between the zero and $168 \mathrm{~h}$ among the treatments. The probability values of $5 \%$ found corroborates the test F. In the evaluation of the model, the ratio $\mathrm{F}_{\text {calculated }} / \mathrm{F}_{\text {tabulated }}$ demonstrated lack of statistic significance for predictive purposes for $\mathrm{B}$ among the times and treatments, what was also observed in $\mathrm{S}_{-} \mathrm{SO}_{4}{ }^{-}$for the times. However, the results were significant and predictive among 
Table 1 - Yield of bacterial cellulose (BC) production in coconut water of ripe (FGCW) and green (FGCW) fruit.

\begin{tabular}{|c|c|c|c|c|c|c|c|c|c|}
\hline \multirow[t]{3}{*}{ Sample } & \multicolumn{7}{|c|}{ Independent variables } & \multirow{2}{*}{\multicolumn{2}{|c|}{$\begin{array}{c}\text { Dependent variable } \\
\text { BC production }\left(\mathrm{g} . \mathrm{L}^{-1}\right)\end{array}$}} \\
\hline & \multirow{2}{*}{$\left(\mathrm{NH}_{4}\right)_{2} \mathrm{SO}_{4}$} & \multirow[t]{2}{*}{$\mathrm{KH}_{2} \mathrm{PO}_{4}$} & \multirow[t]{2}{*}{$\mathrm{MgSO}_{4} 7 \mathrm{H}_{2} \mathrm{O}$} & \multirow[t]{2}{*}{$\mathrm{NaH}_{2} \mathrm{PO}_{4}$} & \multirow[t]{2}{*}{$\mathrm{FeSO}_{4}$} & \multirow[t]{2}{*}{$\mathrm{H}_{3} \mathrm{BO}_{3}$} & \multirow{2}{*}{$\begin{array}{l}\text { Cultivation } \\
\text { manner }\end{array}$} & & \\
\hline & & & & & & & & FRCW & FGCW \\
\hline 1 & -1 & -1 & -1 & -1 & -1 & 1 & 1 & 2.8 & 1.9 \\
\hline 2 & 1 & -1 & -1 & -1 & -1 & -1 & -1 & 2.4 & 3.4 \\
\hline 3 & -1 & 1 & -1 & -1 & -1 & -1 & -1 & 2.5 & 4.1 \\
\hline 4 & 1 & 1 & -1 & -1 & -1 & 1 & 1 & 3.8 & 2.9 \\
\hline 5 & -1 & -1 & 1 & -1 & -1 & -1 & 1 & 3 & 1.9 \\
\hline 6 & 1 & -1 & 1 & -1 & -1 & 1 & -1 & 2.5 & 3.7 \\
\hline 7 & -1 & 1 & 1 & -1 & -1 & 1 & -1 & 2.7 & 4.6 \\
\hline 8 & 1 & 1 & 1 & -1 & -1 & -1 & 1 & 4 & 3.4 \\
\hline 9 & -1 & -1 & -1 & 1 & -1 & -1 & -1 & 3.2 & 4.1 \\
\hline 10 & 1 & -1 & -1 & 1 & -1 & 1 & 1 & 3.6 & 4.8 \\
\hline 11 & -1 & 1 & -1 & 1 & -1 & 1 & 1 & 4 & 4.0 \\
\hline 12 & 1 & 1 & -1 & 1 & -1 & -1 & -1 & 3.6 & 4.9 \\
\hline 13 & -1 & -1 & 1 & 1 & -1 & 1 & -1 & 3.2 & 4.4 \\
\hline 14 & 1 & -1 & 1 & 1 & -1 & -1 & 1 & 3.6 & 3.9 \\
\hline 15 & -1 & 1 & 1 & 1 & -1 & -1 & 1 & 4.5 & 4.3 \\
\hline 16 & 1 & 1 & 1 & 1 & -1 & 1 & -1 & 3.7 & 5.4 \\
\hline 17 & -1 & -1 & -1 & -1 & 1 & 1 & -1 & 2.8 & 3.9 \\
\hline 18 & 1 & -1 & -1 & -1 & 1 & -1 & 1 & 5.3 & 4.1 \\
\hline 19 & -1 & 1 & -1 & -1 & 1 & -1 & 1 & 6 & 3.8 \\
\hline 20 & 1 & 1 & -1 & -1 & 1 & 1 & -1 & 5.9 & 4.7 \\
\hline 21 & -1 & -1 & 1 & -1 & 1 & -1 & -1 & 3.4 & 3.7 \\
\hline 22 & 1 & -1 & 1 & -1 & 1 & 1 & 1 & 4.8 & 3.2 \\
\hline 23 & -1 & 1 & 1 & -1 & 1 & 1 & 1 & 6 & 4.6 \\
\hline 24 & 1 & 1 & 1 & -1 & 1 & -1 & -1 & 3.9 & 4.5 \\
\hline 25 & -1 & -1 & -1 & 1 & 1 & -1 & 1 & 2.7 & 2.8 \\
\hline 26 & 1 & -1 & -1 & 1 & 1 & 1 & -1 & 2.9 & 4.5 \\
\hline 27 & -1 & 1 & -1 & 1 & 1 & 1 & -1 & 4.7 & 5.2 \\
\hline 28 & 1 & 1 & -1 & 1 & 1 & -1 & 1 & 3.1 & 3.4 \\
\hline 29 & -1 & -1 & 1 & 1 & 1 & 1 & 1 & 2.5 & 3.4 \\
\hline 30 & 1 & -1 & 1 & 1 & 1 & -1 & -1 & 2.9 & 2.7 \\
\hline 31 & -1 & 1 & 1 & 1 & 1 & -1 & -1 & 2.7 & 3.1 \\
\hline 32 & 1 & 1 & 1 & 1 & 1 & 1 & 1 & 3.4 & 3.5 \\
\hline 33 & -1 & -1 & -1 & -1 & -1 & -1 & -1 & 1.37 & 1.8 \\
\hline
\end{tabular}

Note: Cultivation manner (-1) static and (1) agitation.

the times and treatments for $\mathrm{K}$, and for $\mathrm{S}_{-} \mathrm{SO}_{4}{ }^{-2}$ only among the treatments.

In fermentations of green coconut water, between the treatments with low, moderated and high production of bacterial cellulose (Table 5), presented higher average consumptions of $\mathrm{Na}(92.2 \%)$ and $\mathrm{NH}_{4}{ }^{+} \mathrm{N}(84.1 \%)$; $\mathrm{Na}$ $(87.1 \%)$ and $\mathrm{NO}_{3}{ }^{-}-\mathrm{N}(80.6 \%) ; \mathrm{NO}_{3}{ }^{-} \mathrm{N}(78.1 \%)$, respectively, and lower consumptions of $\mathrm{S}^{-\mathrm{SO}_{4}}{ }^{-2}(8.9 \%), \mathrm{P}(4 \%)$ and $\mathrm{B}(15.3 \%)$; Fe (22.5\%), P (12.6\%), S-SO ${ }_{4}^{-2}(0.5 \%)$, B (3.6\%) and NTK (7.7\%); NTK $(5 \%)$ and $\mathrm{NH}_{4}{ }^{+}-\mathrm{N}(0 \%)$, re- spectively. Among the minerals $\mathrm{K}, \mathrm{Na}, \mathrm{Fe}, \mathrm{Mg}, \mathrm{P}, \mathrm{S}_{-} \mathrm{SO}_{4}{ }^{-2}$, $\mathrm{B}, \mathrm{NTK}, \mathrm{NO}_{3}{ }^{-}-\mathrm{N}$ and $\mathrm{NH}_{4}{ }^{+}-\mathrm{N}$, the higher and the lowest consumption were observed in treatments 23 (M-BC) 67.5\%; 23 (M-BC) 94.5\%; 13 (M-BC) 43.6\%; 11 (L-BC) 67.7\%; 7 (M-BC) 50.8\%; 10 (M-BC) 64.4\%; 10 (M-BC) $55.9 \%$; 11 (L-BC) and 10 (M-BC) $56.6 \% ; 7$ (M-BC) $91.9 \%$; 3 (L-BC) $88.8 \%$, respectively. Among the minerals $\mathrm{K}, \mathrm{Na}, \mathrm{Fe}, \mathrm{Mg}, \mathrm{P}, \mathrm{S}_{-} \mathrm{SO}_{4}{ }^{-2}, \mathrm{~B}, \mathrm{NTK}, \mathrm{NO}_{3}{ }^{-}-\mathrm{N}$ and $\mathrm{NH}_{4}{ }^{+}-\mathrm{N}$, the lowest consumption were observed in treatments 13 (M-BC) 30.7\%; 26 (M-BC) 50.8\%; 16 (H-BC) $0.8 \% ; 3$ 


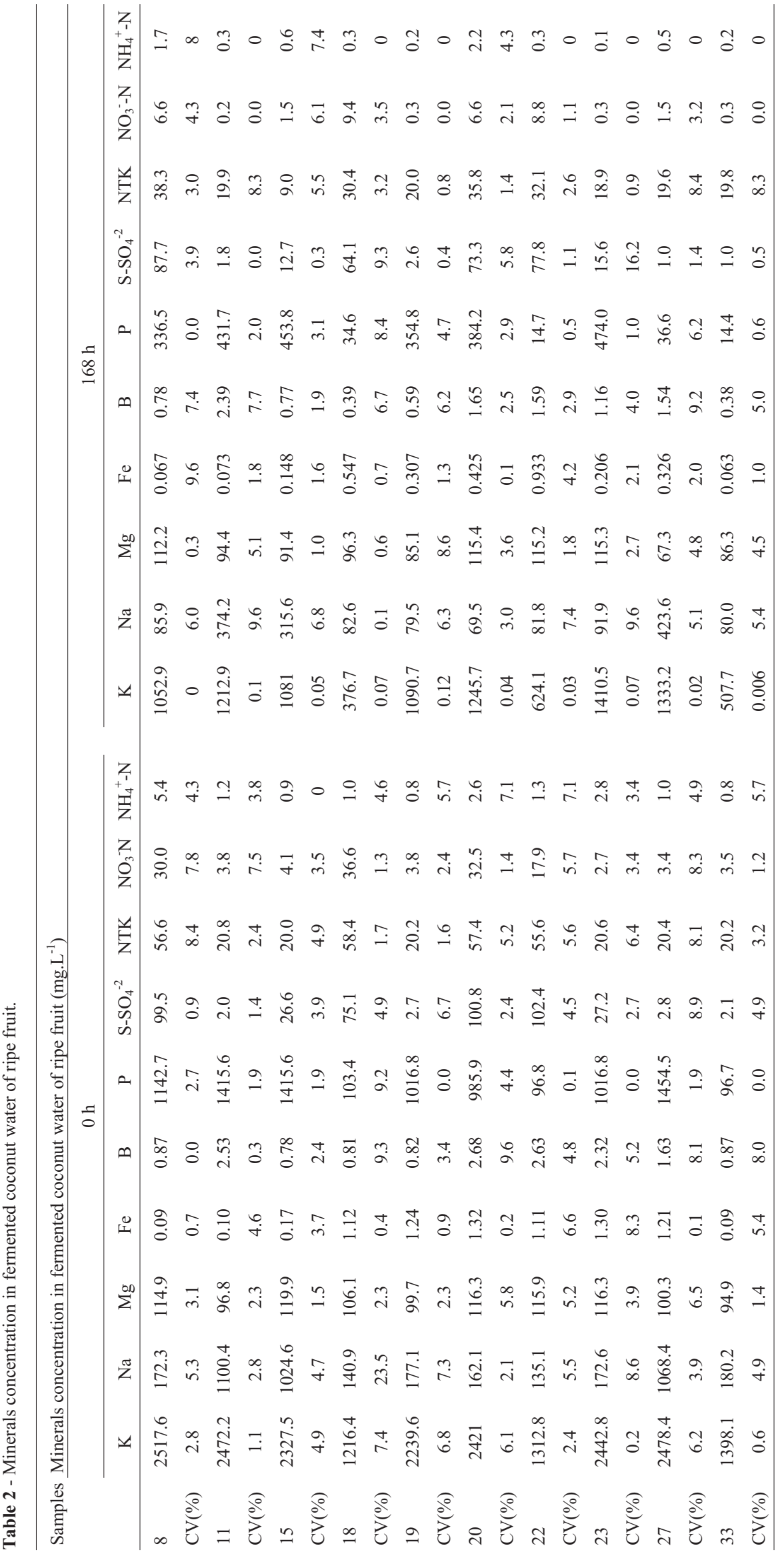




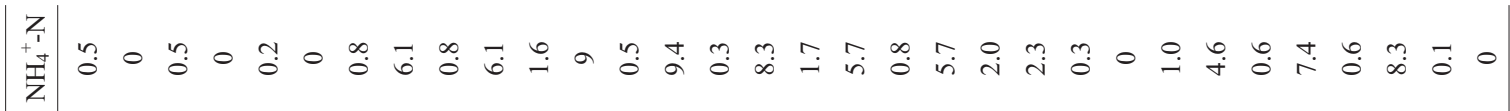

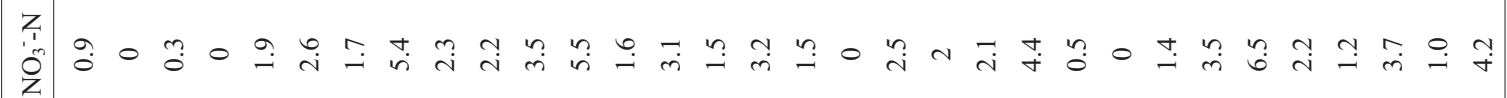
参 萿

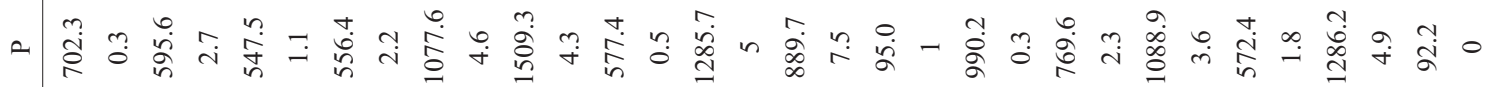

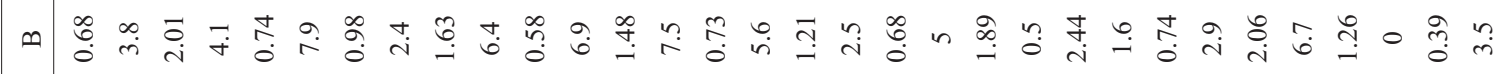

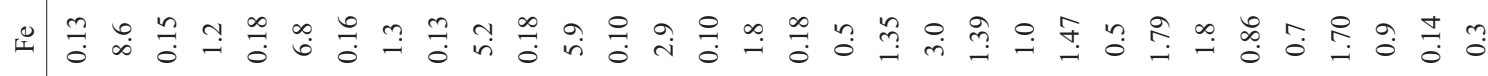

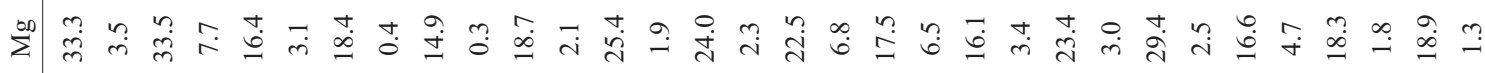

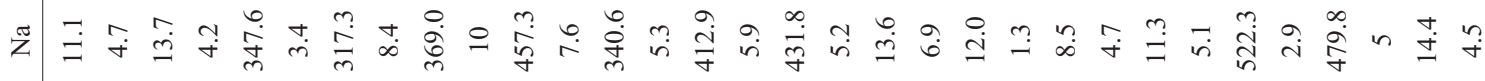

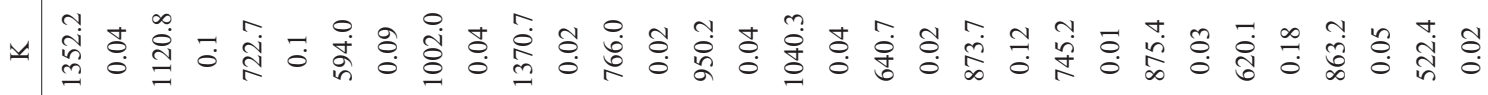

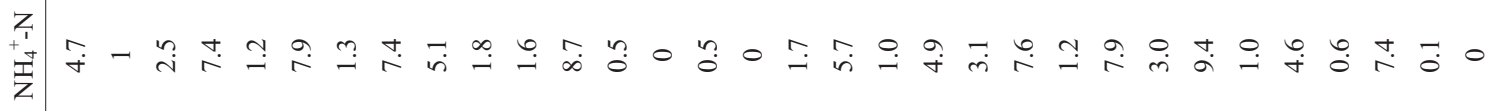
萑

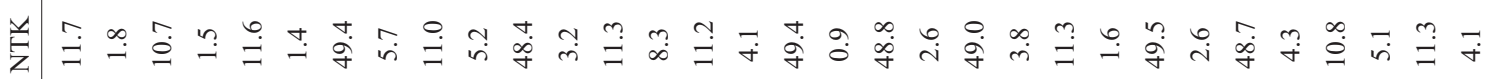

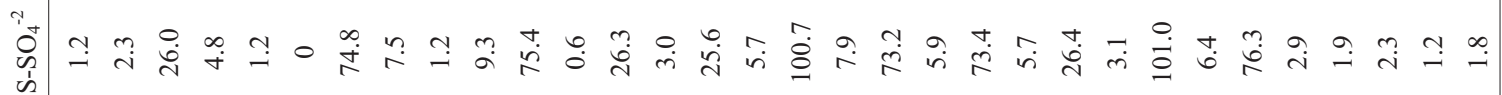

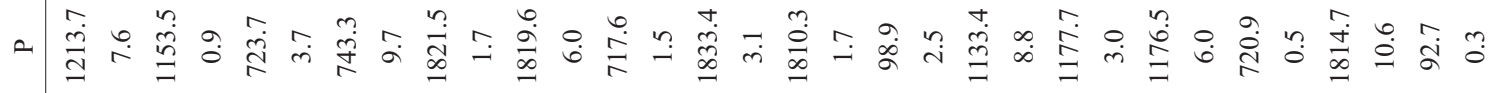
$\frac{1}{0}$

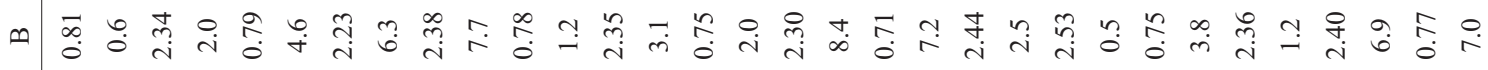

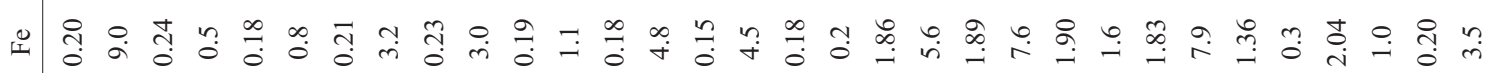

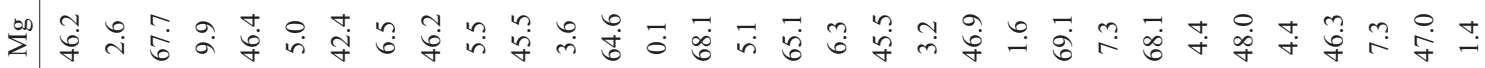

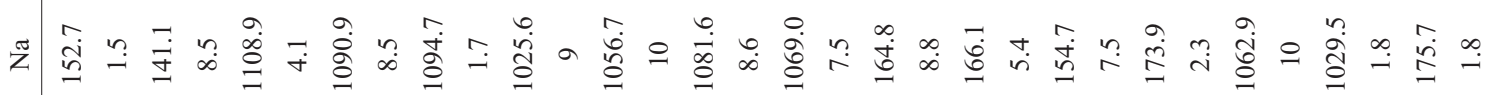

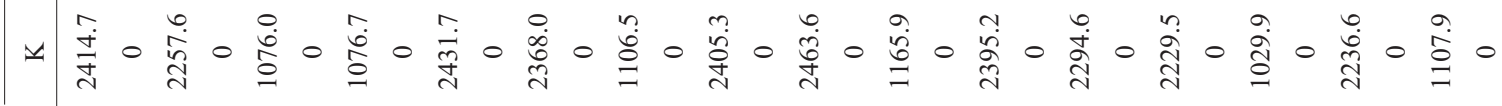


Table 4 - Minerals consumption according to the manner of cultivation.

\begin{tabular}{|c|c|c|c|c|c|c|c|c|c|c|c|}
\hline \multirow{2}{*}{$\begin{array}{l}\text { Cultivation } \\
\text { medium }\end{array}$} & \multirow{2}{*}{$\begin{array}{c}\text { Cultivation } \\
\text { manner }\end{array}$} & \multicolumn{10}{|c|}{ Minerals consumption (\%) } \\
\hline & & $\mathrm{K}$ & $\mathrm{Na}$ & $\mathrm{Fe}$ & $\mathrm{Mg}$ & $\mathrm{P}$ & $\mathrm{S}-\mathrm{SO}_{4}^{-2}$ & B & NTK & $\mathrm{NO}_{3}^{-}-\mathrm{N}$ & $\mathrm{NH}_{4}{ }^{+}-\mathrm{N}$ \\
\hline FRCW & Static & 63 & 65 & 75 & 32 & 97 & 64 & 56 & 37 & 90 & 76 \\
\hline Agitation & 69 & 69 & 84 & 23 & 84 & 52 & 52 & 55 & 94 & 95 & \\
\hline FGCW & Static & 63 & 92 & 43 & 65 & 50 & 53 & 48 & 46 & 91 & 88 \\
\hline Agitation & 67 & 94 & 38 & 67 & 40 & 64 & 55 & 56 & 85 & 85 & \\
\hline
\end{tabular}

Table 5 - Minerals consumption according to the bacterial cellulose production.

\begin{tabular}{|c|c|c|c|}
\hline \multirow[t]{2}{*}{ Cultivation medium } & \multirow[t]{2}{*}{$\mathrm{CB}$} & \multicolumn{2}{|c|}{ Minerals consumption } \\
\hline & & Higher consumption $(\%)$ & Lower consumption $(\%)$ \\
\hline \multirow[t]{3}{*}{ FRCW } & L-BC & $\mathrm{NO}_{3}{ }^{-}-\mathrm{N}(87.7)$ & $\operatorname{Mg}(2.4)$ \\
\hline & $\mathrm{M}-\mathrm{BC}$ & $\mathrm{Na}(69.1) ; \mathrm{P}(91.1)$ & $\mathrm{B}(2.9) ; \mathrm{Mg}(0.6)$ \\
\hline & $\mathrm{H}-\mathrm{BC}$ & $\mathrm{NO}_{3}^{-}-\mathrm{N}(86.3) ; \mathrm{NH}_{4}^{+}-\mathrm{N}(84.5)$ & $\mathrm{Mg}$ (3.6); NTK (1.1) \\
\hline \multirow[t]{3}{*}{ FGCW } & $\mathrm{L}-\mathrm{BC}$ & $\mathrm{Na}(92.2) ; \mathrm{NH}_{4}{ }^{+}-\mathrm{N}(84.1)$ & $\mathrm{S}_{-} \mathrm{SO}_{4}^{-2}$ (8.9); P (4.0); B (15.3) \\
\hline & $\mathrm{M}-\mathrm{BC}$ & $\mathrm{Na}(87.1) ; \mathrm{NO}_{3}^{-}-\mathrm{N}(80.6) ; \mathrm{Mg}(65.1)$ & $\mathrm{Fe}(22.5) ; \mathrm{P}(12.6) ; \mathrm{S}^{-\mathrm{SO}_{4}}{ }^{-2}(0.5) ; \mathrm{B}(2.4) ; \mathrm{NTK}$ (5.2) \\
\hline & $\mathrm{H}-\mathrm{BC}$ & $\mathrm{NO}_{3}{ }^{-}-\mathrm{N}(78.1)$ & NTK $(5.0) ; \mathrm{NH}_{4}^{+}-\mathrm{N}(0)$ \\
\hline
\end{tabular}

Note - Low production of bacterial cellulose (L-BC); Moderated production of bacterial cellulose (M-BC); High of bacterial cellulose (H-BC).

(L-BC) $27.8 \% ; 33$ (L-BC) $0.5 \% ; 12$ (L-BC) $0.5 \% ; 24$ (M-BC) $1.3 \% ; 15$ (L-BC) $2.4 \% ; 26$ (M-BC) $45.2 \% ; 16$ (H-BC) $0 \%$, respectively.

In fermentations of green coconut water, the minerals $\mathrm{Na}, \mathrm{Mg}, \mathrm{Fe}, \mathrm{B}, \mathrm{P}, \mathrm{S}-\mathrm{SO}_{4}{ }^{-2}$, with percentage of explained variance higher or equal $90 \%$, submitted to regression analysis, indicated the existence of a significant difference $(\mathrm{p} \leq 0.05)$ for both factors, times and treatments. The ratio $\mathrm{F}_{\text {calculated }} / \mathrm{F}_{\text {tabulated }}$ indicated significance of the models for $\mathrm{Na}, \mathrm{Mg}$ and $\mathrm{P}$ among the times, and in the treatments such results were observed in $\mathrm{S}_{-} \mathrm{SO}_{4}{ }^{-2}, \mathrm{~B}, \mathrm{P}$ and Fe. However, the model did not demonstrate significance for predictive purposes among the times for the minerals $\mathrm{Fe}, \mathrm{B}$ and $\mathrm{S}_{-} \mathrm{SO}_{4}{ }^{-2}$, and in the treatments for $\mathrm{Na}$ and $\mathrm{Mg}$.

The low concentration of $\mathrm{P}$ in treatments $16(50.8 \%)$ and 27 (29.1\%) with high production of bacterial cellulose in fermentations of green coconut water, could be related to the important function such element has in the bacterial cellulose biosynthetic route in strains of Acetobacter, in the nucleotide combined form (ATP, ADP, UDP, UTP, UGP) and inorganic phosphate. Some phosphorylated substances are involved with the energy storage (such as ATP) and act as metabolic processes regulators, because many enzymes become active when phosphorylated (Benziman and Mazaver, 1973; Weinhouse and Benziman, 1974).

The low consumption of Fe was observed in fermentations of green coconut water with moderated production of cellulose. However, the action of ferric and ferrous ions in the bacterial cellulose production could stimulate the combination of phosphorated compounds of high energy, what contributes to cellulose biosynthesis (Chávez-Pacheco et al., 2004). Such significance was reported by Chávez-Pacheco et al. (2006) when verified an increase in the production of cellulose through changing the concentration of phosphate from $20-200 \mathrm{mmol} . \mathrm{L}^{-1}$ until it reached 100 mmol. $\mathrm{L}^{-1}$.

Low consumption of $\mathrm{Mg}$ and NTK was observed in fermented ripe coconut water, with low, moderated, and high production of bacterial cellulose. However, such aspect was not observed by Son et al. (2003) when the effect of several nutrients in the production of bacterial cellulose by Acetobacter sp. V6 was examined, showing the increase in the amount of bacterial cellulose when the concentration of $\mathrm{MgSO}_{4} .7 \mathrm{H}_{2} \mathrm{O}$ was increased to $0.08 \%, \mathrm{FeSO}_{4} .7 \mathrm{H}_{2} \mathrm{O}$ to $0.0005 \%, \mathrm{H}_{3} \mathrm{BO}_{3}$ to $0.0003 \%, \quad\left(\mathrm{NH}_{4}\right)_{2} \mathrm{SO}_{4}$ to $0.2 \%$, $\mathrm{NaH}_{2} \mathrm{PO}_{4} \cdot 12 \mathrm{H}_{2} \mathrm{O}$ and $\mathrm{KH}_{2} \mathrm{PO}_{4}$ to $0.3 \%$. According to Kyazanova et al. (2009), it was verified that cells of Acetobacter xylinum decrease the concentration of phosphates in the medium from 5 to 2.5 or $0.3 \mathrm{mM}$ during incubation in the presence of $\mathrm{Mg}^{2+}$ and glucose, or $\mathrm{Mg}^{2+}$ and casamino acid. Other activities of $\mathrm{Mg}^{+2}$ were observed by García et al. (1974) in the formation of various lipophilic components (lipid diphosphate $\alpha$-glucose, lipid diphosphate $\alpha$-celobiose and lipid monophosphate $\beta$-galactose) from the enzymatic system, in the presence of UDP-Glc (uridine diphosphate glucose), which has an important role in the lipid formation when added at 3-6 mM, having influence on the bacterial polysaccharide biosynthesis.

Boron was more consumed in treatment 33 (control) (Table 2 e 3), in both fermentations. This characteristic was also present in the treatments with moderated production of 
bacterial cellulose, what suggests a certain degree of contribution of this mineral in such production.

The treatments with moderated production of bacterial cellulose, in fermented ripe coconut water and fermentations of green coconut water, demonstrated a significant consumption of NTK. This aspect was also reported by Budhiono et al. (1999) when observing characteristics such as the linear increase of bacterial cellulose production in relation to thickness, and humid and dry weight when a nitrogen source was added to the fermentation process. The sources with nitrogen and phosphate were more effective in the production of bacterial cellulose. According to Kurosumi et al. (2009), when investigating the use of various fruit juices as source of carbon for the production of bacterial cellulose by Acetobacter xylinum NBRC 13693, it was observed that the adding of yeast extract and peptones as source of nitrogen was essential for cellular culture and bacterial cellulose production.

In the study developed by Baruque-Ramos et al. (2001) the inorganic nitrogen in the medium did not change significantly along the cultivation time, whereas the organic nitrogen consumption was linearly related to cell growth, with constant yield factors (average of 8.44).

The N-NH${ }_{4}^{+}$was important for the treatments with high bacterial cellulose production in fermentations of ripe coconut water. However, in fermentations of green coconut water, such element did not contribute much. In the study developed by Jagannath et al. (2009) the maximum of thickness in coconut cream was verified in $\mathrm{pH} 4$, with $10 \%$ of saccharose and $0.5 \%$ of ammonium sulfate.

Considering the medium of cultivation, among the minerals of fermented ripe coconut water, the higher consumption was of $\mathrm{P}$, with $97.4 \%$, and the lowest was of $\mathrm{Mg}$, with $0.6 \%$ (Table 6 ). In fermentations of green coconut water, Na was the most consumed mineral in the process, with $94.5 \%$, while $\mathrm{Fe}$, with $43.6 \%$, presented the lowest consumption. The minerals K, B, S- $\mathrm{SO}_{4}{ }^{-2}$, NTK, $\mathrm{NH}_{4}{ }^{+}-\mathrm{N}$, and $\mathrm{NO}_{3}{ }^{-} \mathrm{N}$ had similar consumption in both fermentative processes, with ratios of $68.2 \%, 56.0 \%, 64.6 \%, 55.9 \%, 92.0 \%$, and $93.3 \%$, respectively.

Therefore, in fermentations of ripe coconut water the Acetobacter xylinum (ATCC 23769) showed higher consumption of minerals $\mathrm{K}, \mathrm{Fe}, \mathrm{P}, \mathrm{S}_{-} \mathrm{SO}_{4}{ }^{-2}, \mathrm{~B}, \mathrm{~N}-\mathrm{NO}_{3}{ }^{-}$and $\mathrm{N}-\mathrm{NH}_{4}{ }^{+}$and higher production of bacterial cellulose. This fact can be related to the higher saccharose concentration in the culture medium, due to the fruit maturation degree (Carvalho et al., 2006). The papers developed by (Chávez-
Pacheco et al., 2004; Jagannath et al., 2009; Krystynowicz, et al., 2002) indicate culture medium with saccharose to keep and improve the microorganism development.

In treatment 33 (control), the minerals analyzed were in higher concentrations in fermented ripe coconut water in the beginning of the process (Table 2), fact also observed in other studies about the grade of such minerals in ripe and green coconut water (Carvalho et al., 2006; Santoso et al., 1996; Pue, 1992; Srebernich, 2000). At the end of the fermentative process, there was a high consumption, in decreasing order, of: $\mathrm{B}>\mathrm{K}, \mathrm{P}, \mathrm{S}_{-} \mathrm{SO}_{4}{ }^{-2}$ and $\mathrm{NH}_{4}{ }^{+}-\mathrm{N}>\mathrm{NO}_{3}{ }^{-}-\mathrm{N}$ $>\mathrm{Mg}>\mathrm{Fe}$ and $\mathrm{Na}>\mathrm{NTK}$ in fermented ripe coconut water. In fermentations of green coconut water, the greatest reductions were observed for the minerals $\mathrm{B}>\mathrm{Na}>\mathrm{Ke} \mathrm{NH}_{4}{ }^{+} \mathrm{N}$ $>\mathrm{Fe}>\mathrm{Mg}>\mathrm{NO}_{3}^{-}-\mathrm{N}>\mathrm{NTK}>\mathrm{S}^{-} \mathrm{SO}_{4}^{-2}>\mathrm{P}$.

\section{Multivariate analyses}

Considering the principal components analysis (PCA), it was possible to describe $99.4 \%$ of the data with nine components, being $32.7 \%$ of the total variance described by the first principal component (PC1) and 12.7\% by third main component (PC3).

The conjoint analysis of the scores and weight graphics (Figures 1a and $\mathrm{b}$ ) showed that first main component (PC1) divided the treatments into two classes in function of the fermentation times zero and $168 \mathrm{~h}$. This analysis also allowed the observation of which zero hour fermentations presented greater $\mathrm{S}_{-} \mathrm{SO}_{4}{ }^{-2}, \mathrm{NTK}, \mathrm{NO}_{3}{ }^{-}-\mathrm{N}, \mathrm{NH}_{4}{ }^{+}-\mathrm{N}$ and $\mathrm{K}$, and $168 \mathrm{~h}$ of $\mathrm{Na}, \mathrm{Fe}, \mathrm{Mg}, \mathrm{P}$, and $\mathrm{B}$ concentrations.

Third main component (PC3) divided the minerals into two regions, considering the culture medium. The treatments with positive values, such as $\mathrm{Fe}, \mathrm{P}, \mathrm{B}, \mathrm{S}_{-} \mathrm{SO}_{4}{ }^{-2}$ and NTK discriminate fermentations of green coconut water. In turn, the negative values of the weight correspond to the variables $\mathrm{Na}, \mathrm{Mg}, \mathrm{NH}_{4}{ }^{+}-\mathrm{N}$, and $\mathrm{NO}_{3}{ }^{-} \mathrm{N}$ and discriminate significantly the fermented ripe coconut water.

In the beginning of the fermentative process, the minerals in higher concentrations are $\mathrm{K}, \mathrm{NH}_{4}{ }^{+}-\mathrm{N}^{-}$and $\mathrm{NO}_{3}{ }^{-}-\mathrm{N}$ in fermented ripe coconut water, and $\mathrm{S}_{-} \mathrm{SO}_{4}{ }^{-2}$ and NTK in fermentations of green coconut water. After $168 \mathrm{~h}$, low consumption of $\mathrm{Na}$ and $\mathrm{Mg}$ was observed for fermented ripe coconut water, and high consumption of the minerals $\mathrm{Fe}, \mathrm{P}$, $\mathrm{B}, \mathrm{S}_{-} \mathrm{SO}_{4}{ }^{-2}$, and NTK. In fermentations of green coconut water, the minerals $\mathrm{Fe}, \mathrm{P}, \mathrm{B}$ demonstrated a lower consumption, and $\mathrm{K}, \mathrm{Na}, \mathrm{Mg}, \mathrm{NO}_{3}{ }^{-} \mathrm{N}$ and $\mathrm{NH}_{4}{ }^{+}-\mathrm{N}$ presented a significant reduction. Those results revealed the inverse re-

Table 6 - Minerals consumption according to the cultivation medium.

\begin{tabular}{|c|c|c|c|c|c|c|c|c|c|c|}
\hline \multirow[t]{2}{*}{ Cultivation manner } & \multicolumn{10}{|c|}{ Minerals consumption (\%) } \\
\hline & $\mathrm{K}$ & $\mathrm{Na}$ & $\mathrm{Fe}$ & $\mathrm{Mg}$ & $P$ & $\mathrm{~S}-\mathrm{SO}_{4}^{-2}$ & B & NTK & $\mathrm{NO}_{3}^{-}-\mathrm{N}$ & $\mathrm{NH}_{4}^{+}-\mathrm{N}$ \\
\hline FACM & 69.0 & 69.1 & 84.1 & 32.9 & 97.4 & 64.9 & 56.1 & 55.2 & 94.7 & 95.2 \\
\hline FACV & 67.5 & 94.5 & 43.6 & 67.7 & 48.3 & 64.4 & 55.9 & 56.6 & 91.9 & 88.8 \\
\hline
\end{tabular}



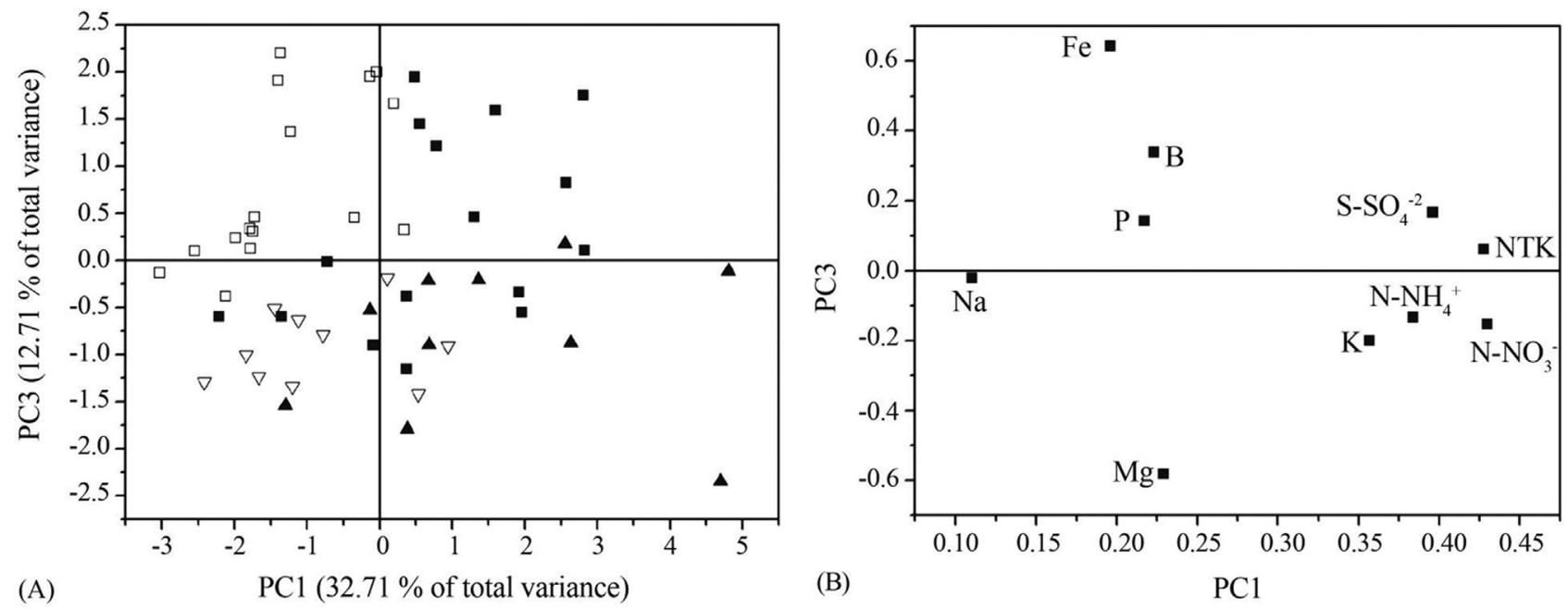

Figure 1 - Scores (A) and weights (B) graphics of PCA analysis of the mineral concentration percentage in the fermentation treatments: FRCW-0 h $(\mathbf{A})$ and FRCW-168 h ( $\nabla)$, FGCW-0 h (ם) and FGCW-168 h (口).

lation to the consumption of such minerals among the culture media.

Iron and $\mathrm{Mg}$ are the minerals with greater weight values in the positive and negative regions, respectively, in first main component (PC1). In third main component (PC3), $\mathrm{NO}_{3}{ }^{-}-\mathrm{N}$ presented greater weight value in the negative region on the right side, and $\mathrm{Na}$ on the left side (Figure $1 b)$.

\section{Conclusion}

Among the culture media, the treatments maintained under agitation presented high mineral reductions, in both processes. Considering the culture media, fermented ripe coconut water presented high mineral consumption $(\mathrm{K}, \mathrm{Fe}$, $\mathrm{P}, \mathrm{S}-\mathrm{SO}_{4}{ }^{-2}, \mathrm{~B}, \mathrm{NO}_{3}{ }^{-} \mathrm{-N}$ and $\mathrm{NH}_{4}{ }^{+}-\mathrm{N}$ ) and, in fermentations of green coconut water, the higher consumptions were from $\mathrm{Na}, \mathrm{Mg}$ and NTK.

In relation to bacterial cellulose production, both fermentative processes presented higher consumptions of $\mathrm{Na}$ and $\mathrm{NO}_{3}^{-}-\mathrm{N}$, in the treatments with moderated and high production of cellulose, respectively. The treatments with low bacterial cellulose production presented higher consumption of $\mathrm{NO}_{3}^{-}-\mathrm{N}$ in fermented ripe coconut water, and $\mathrm{Na}$ and $\mathrm{NH}_{4}{ }^{+} \mathrm{N}$ in fermentations of green coconut water, what suggests a high contribution of such minerals in $\mathrm{BC}$ production. Lower reductions of NTK were verified in treatments with moderated and high cellulose production, in both fermentations. In the treatments with low cellulose production, there was a lower consumption of $\mathrm{Mg}$ and NTK in $\mathrm{FRCW}$ and of $\mathrm{S}_{-} \mathrm{SO}_{4}{ }^{-2}, \mathrm{P}$, and $\mathrm{B}$ in fermentations of green coconut water. The higher bacterial cellulose production, $6 \mathrm{~g} . \mathrm{L}^{-1}$, was verified in the fermentative containing coconut water of ripe fruit, $\mathrm{KH}_{2} \mathrm{PO}_{4}\left(5000 \mathrm{mg} \cdot \mathrm{L}^{-1}\right), \mathrm{FeSO}_{4}$ $\left(5 \mathrm{mg} . \mathrm{L}^{-1}\right), \mathrm{NaH}_{2} \mathrm{PO}_{4}\left(300 \mathrm{mg} \cdot \mathrm{L}^{-1}\right)$ and kept under agitation.
The main components analysis (PCA) made it possible to differentiate the minerals that have high influence in the culture media. In fermented ripe coconut water, $\mathrm{Na}$, $\mathrm{Mg}, \mathrm{NH}_{4}{ }^{+}-\mathrm{N}$, and $\mathrm{NO}_{3}{ }^{-}-\mathrm{N}$ were more significant, and $\mathrm{Fe}, \mathrm{P}$, $\mathrm{B}, \mathrm{S}_{-} \mathrm{SO}_{4}{ }^{-2}$, and NTK discriminated fermentations of green coconut water. At the end of the fermentative process, the results revealed the inverse relation in the mineral consumption among the culture media, with high consumptions of $\mathrm{Fe}, \mathrm{P}$, and $\mathrm{B}$ (fermented ripe coconut water), and $\mathrm{Na}$ and $\mathrm{Mg}$ (fermentations of green coconut water).

\section{Acknowledgments}

The authors thank the State University of Ponta Grossa, Technological Federal of Paraná and the Federal of Paraná for the operational infrastructure and to the CNPq for the scholarships awarded.

\section{References}

Baruque-Ramos J, Hiss H, Vicentin MA, Paz MF, Peixoto A, Leal MBB, Sato RA, Vassoler UM, Raw I (2001) Nitrogen consumption during batch cultivation of Neisseria meningitides (serogroup C) in frantz medium. Braz J Microbiol 32:305310.

Benziman M, Mazaver A (1973) NAD and NAD phosphate specific glucose-6-phosphate dehydrogenases of Acetobacter xylinum and their role in the regulation of the pentose cycle. J Biochem Chem 248:1603-1608.

Budhiono A, Rosidi B, Taher H, Iguchi M (1999) Kinetic aspects of bacterial cellulose formation in nata-de-coco culture system. Carbohy Polym 40:137-143.

Carvalho JM, Maia GA, Sousa PHM, Maia Junior GA (2006) Água-de-coco: Propriedades nutricionais, funcionais e processamento. Semin Ciênc Agra 27:437-452.

Chávez-Pacheco JL, Yee SM, Zentella MC, Marván EE (2004) Celulosa Bacteriana en Gluconacetobacter xylinum: Biosíntesis y Aplicaciones. Rev Esp Cienc Quim Biolog 7:18-25. 
Chávez-Pacheco JL, Yee-Martínez S, Contreras ML, ManzoGómez S, Hernández-Membrillo J, Escamilla JE (2005) Partial bioenergetic characterization of Gluconacetobacter xylinum cells released from cellulose pellicles by a novel methodology. J Appl Microbiol 99:1130-1140.

Fontana JD, Joerke CG, Baron M, Marashchin M, Ferreira AG, Torriani I, Souza AM, Soares MB, Fontana MA, Guimaraes MF (1997) Acetobacter cellulosic biofilms search for new modulators of cellulogenesis and native membrane treatments. Appl Biochem Biotechnol 63:327-338.

García RC, Recondo E, Dankert M (1974) Polysaccharide biosynthesis in Acetobacter xylinum: Enzymatic synthesis of lipid diphosphate and monophospate sugars. Eur J Biochem 43:93-105.

Jagannath A, Manjunatha SS, Ravi N, Raju PS (2009) The effect of different substrates and processing conditions on the textural characteristics of bacterial cellulose (nata) produced by Acetobacter xylinum. J Food Proc Engineer 34:593-608.

Jonas R, Farah LF (1998) Production and application of microbial cellulose. Polym Degrad Stabil 59:101-106.

Krystynowicz A, Czaja W, Polomorski L, Kolodzicjczyk M, Bielecki S (2002) Factors affecting the yield and properties of bacterial cellulose. J Ind Microbiol Biotechnol 29:189195.

Kurosumi A, Sasaki C, Yamashita Y, Nakamura Y (2009) Utilization of various fruit juices as carbon source for production of bacterial cellulose by Acetobacter xylinum NBRC 13693 . Carbohy Polym 76:333-335.

Kyazanova LP, Suzina NE, Kulakovskaya TV, Kulaev IS (2009) Phosphate accumulation of Acetobacter xylinum. Arch Microbiol 191:467-471.

Lima UA, Aquarone E, Borzani W, Schmidell W (2001) Biotecnologia Industrial: Processos Fermentativos e Enzimáticos. Edgard Blücher, São Paulo, 593 pp.

Malavolta E, Vitti GC, Oliveira SA (1997) Avaliação do Estado Nutricional das Plantas: Princípios e Aplicações. Potafos, Piracicaba, 319 pp.

Martins LO, Brito LC, Sá-Correia I (1990) Roles of $\mathrm{Mn}^{2+}, \mathrm{Mg}^{2+}$ and $\mathrm{Ca}^{2+}$ on alginate biosynthesis by Pseudomonas aeruginosa. Enz Microbial Technol 12:794-799.

Masaoka S, Ohe T, Sakota N (1993) Production of cellulose from glucose by Acetobacter xylinum. J Fermen Bioeng 75:18-22.

Nohata Y, Kurane R (1997) Complete defined medium for largescale production of polysaccharide bioabsorbent from Alcaligenes latus B-16. J Fermen Bioeng 83:116-117.

Okiyama A, Shirae H, Kano H, Yamanaka S (1992) Bacterial cellulose I. Two-stage fermentation process for cellulose production by Acetobacter aceti. Food Hydrocol 6:471-477.
Park W, Kim HS, Kwon SM, Hong YH, Jin HJ (2009) Synthesis of bacterial celluloses in multiwalled carbon nanotube-dispersed medium. Carbohy Polym 77:457-463.

Pue, AG (1992) Preliminary studies on changes in coconut water during maturation of fruit. Scien N Guin 8:81-84.

Ross P, Aloni Y, Weinhouse H, Michaeli D, Weinberger-Ohana P, Mayer R, Benziman M (1986) Control of cellulose synthesis in Acetobacter xylinum. A unique guanil oligonucleotide is the activator of the cellulose synthetase. Carbohy Res 149:101-117.

Santoso U, Kubo K, Ota T, Tadokoro T, Maekawa A (1996) Nutrient composition of kopyor coconuts (Cocos nucifera L.). Food Chem 57:229-304.

Saxena IM, Kudlicka K, Okuda K, Brown Jr RM (1994) Characterization of genes in the cellulose-synthesizing operon (acs operon) of Acetobacter xylinum: Implications for cellulose crystallization. J Bacteriol 176:5735-5752.

Saxena IM, Brown Jr RM (2001) Structure-function characterization of cellulose synthase: Relationship to other glycosyltransferase. Phytochem 57:1135-1148.

Son HJ, Kim HG, Lee SJ (2001) Optimization of fermentation conditions for the production of bacterial cellulose by a newly isolated Acetobacter sp. A9 in shaking cultures. Biotechnol Appl Biochem 33:1-5.

Son HJ, Kim, HG, Kim KK, Kim HS, Kim YG, Lee SJ (2003) Increased production of bacterial cellulose by Acetobacter sp. V6 in synthetic media under shaking culture conditions. Biores Technol 86:215-219.

Srebernich SM (2000) Teores de minerais na água de coco da variedade gigante relacionada a idade do fruto. In: XVII Congresso Brazileiro de Ciência e Tecnologia de Alimentos. Foratleza, Ceará. Livro de Resumo v. 2, pp 5220.

Trabulsi LR, Alterthum F (1999) Microbiologia. 3rd edition. Atheneu, São Paulo, 586 pp.

Tsuchida T, Yoshinaga F (1997) Production of bacterial cellulose by agitation culture systems. Pur Appl Chem 69:2453-2458.

Vandamme EJ, Baets S, Vabaelen A, Joris K, Wuff P (1998) Improved production of bacterial cellulose and its application potencial. Polym Degrad Stability 59:93-99.

Weinhouse H, Benziman M (1974) Regulatoin of hexose phosphate metabolism in Acetobacter xylinum. J Biochem 138:537-542.

Wong TY (1993) Effects of calcium on sugar transport in Azotobacter vinelandii. Appl Environmen Microbiol 59:89-92.

All the content of the journal, except where otherwise noted, is licensed under a Creative Commons License CC BY-NC. 